\title{
Software Reliability: Metrics
}

\author{
Durga Patel \\ AIM \& ACT \\ Banasthali University \\ Tonk,Rajasthan
}

\author{
Pallavi \\ AIM \& ACT \\ Banasthali University \\ Tonk ,Rajasthan
}

\begin{abstract}
For the critical business application, continuous availability is the requirement, and software reliability is an important component of continuous application availability. Reliability implies probability. Program may contain no error and its reliability is unity. If the program contains error then its reliability is zero. Need of complex system is increased more rapidly. In early 1970 s Software also become a matter of concern primarily due to a continuing increase in the cost of Software relative to hardware in both the development and the operational phase of the system. Software is essential in instrument for transforming a discrete set of inputs into a discrete set of output. Since, Software is produced by humans; the finished product is often imperfect. Therefore, Software Reliability is important and measuring technique to detect the failure. There has lot of work done in field of software reliability estimation.
\end{abstract}

\section{Keywords}

Software Reliability (SR), software reliability metrics, software measurement, and complexity metrics

\section{INTRODUCTION}

According to IEEE, "Reliability is defined as the ability of a system or component to perform its required function under a given period of time and conditions". Software reliability is considered as failure free operation. It covers all the categories such as Analysis and design, Coding, Testing and Hardware systems. According to the study, in July 2013 done by different authors Reliability is defined in three categories that are improvement, modeling and measurement. The Software Assurance Technology Center (SATC) at NASA tried to apply Models and Metrics to improve quality and reliability of software product. According to the definitions given by IEEE and NASA, Software reliability is composed of Error prevention, Fault detection and removal and Measurements to maximize reliability. In this paper, we are going to discuss about the various factors which affect the Software Reliability.

\section{Software reliability}

Software reliability is considered as one of most important assessment processes during software development. Software reliability is defined as stability or life of the software system with different properties. Reliability is referring as 'how well software is met up the requirements of the client. Software reliability is a measure in planning and controlling the resources during the development process, so that high quality software can be developed. [1]

\section{Expression of SWR:}

The expression of Software reliability is based on probability and is given by probability of success at time $t, P s(t)$.

$$
\begin{aligned}
\mathrm{R}(\mathrm{t}) & =\operatorname{Ps}(\mathrm{t})=1-\operatorname{Pf}(\mathrm{t})=1-\mathrm{F}(\mathrm{t}) \\
& =1-\mathrm{f}(\mathrm{x}) \mathrm{dx}
\end{aligned}
$$

Where $\mathrm{R}(\mathrm{t})=$ Reliability of software at time $\mathrm{t}$

\author{
Ps $(t)=$ Probability of failure \\ $\operatorname{Pf}(\mathrm{t})=$ Probability of failure. \\ $\mathrm{F}(\mathrm{t})=$ Failure distribution function . \\ $\mathrm{f}(\mathrm{x})=$ Failure density function .
}

Density function is not convenient for study of failure data and we normally consider hazard rate or failure rate $\mathrm{Z}(\mathrm{t})$. $\mathrm{SWR}$ in terms of hazard rate $\mathrm{z}(\mathrm{t})$ is given as

$\mathrm{R}(\mathrm{t})=\exp [-\mathrm{z}(\mathrm{x}) \mathrm{dx}]$

This expression shows that the reliability of software increased with passage of time.

\section{LITERATURE REVIEW}

According to SATC, they have introduced the metric for measuring the reliability of a software product. Accordingly they have decided to cover those areas where error prevention technique and metrics is applied to impact the reliability i.e.: requirements, coding and testing. They have given their own metrics in the form such as:

\section{Requirement Reliability metrics}

Requirement analysis is an important factor while considering any software. Any phrases such as TBD (to be determined) and TBA (to be added) since the lack of this phrases may have a negative impact on the design. The requirements should be in stable form so that the designing and implementation part should proceed. There are mainly three standard formats which are given by: IEEE, DOD and NASA.

The requirements must be complete, structured and easy to apply. Due to the correctness in the requirement many software industry have been aided for the creation and management of software. The software developed by them is: Automated Requirements Measurement (ARM) to scan the text of requirement specification and search for specific words and phrases.

Those words indicate the document's quality as requirements specification and have been applied to 56 NASA specification document. As a result 7 measures were developed: Lines of Text, Imperatives, Continuances, Directives, Weak phrases, incomplete and options. In this the structure is evaluated by identifying the requirements and by hierarchical numbering them.

\section{Design and Code Reliability metrics}

Since the design and coding of all the software is not same. If the module is more complex it will be more difficult to understand and has a direct impact on the software's quality. Size is one of the oldest form for software measurement as it is also a quality indicator. This in turn had an impact on software maintainability and on the basis of complexity there are:

1. Statement count: According to the abstract viewpoint, the more detail that an entity posses; the 
more difficult it sis to understand. Due to its simplicity it is used worldwide.

2. Halstead Software Science: In this all the operators and operands are taken in to consideration and based on that value :

$$
\begin{aligned}
& \mathrm{n} 1=\text { number of unique operators } \\
& \mathrm{n} 2=\text { number of unique operands } \\
& \mathrm{N} 1=\text { total number of operators } \\
& \mathrm{N} 2=\text { total number of operands } \\
& \text { Then program Volume is: } \\
& V=(N 1+N 2) \log _{2}(n 1+n 2)
\end{aligned}
$$

Programming effort is calculated as:

$$
\mathrm{E}=\mathrm{V} 2 / \mathrm{V}^{*}
$$

Where,

$\mathrm{V}^{*}$ is the minimum possible volume for program.

This has certain drawback as the most effort is required to produce the initial part of program.

3. McCabe's Number or Cyclomatic Complexity

McCabe ([Mccab 76]) has defined the complexity of a program to be:

$$
\begin{gathered}
v=e-n+2 p \\
\text { Where } \\
e=\text { number of edges in a program flow graph } \\
n=\text { number of nodes } \\
p=\text { number of connected components }
\end{gathered}
$$

It can be calculated by counting the number of independent paths. This method has been used by SATC.SATC has found the relation between the size and complexity and indicated that the modules with high complexity and large size is less reliable as compared to modules with low size and high complexity. It also has a drawback as for many different complex program the complexity can be same.

\section{Testing Reliability metrics}

Testing metrics must take two approaches: the first one include evaluation of test plan and the other one is related to the evaluation of the number of errors in code and rate of finding/fixing them. In the first approach it is functional specific in which multiple cases are generated .In this test case, belong to one system state and test function on the basis of requirement. The objective is that if it pass the test than that required functionality will be added in the product. In this each of the test cases must be tested once and some of them will be tested multiple times as they are involved in different ways in the software. In the event of finding an error SATC has developed musa model to compute nonlinear approximation to cumulative errors. In addition to relate it to manpower efforts modified musa model has been used which uses the integral of a Rayleigh function.

As now a days developing software has become a more complex and time consuming task. The need for highly reliable system is ever increasing. The software development life cycle consist of five phases: analysis, design, coding, testing and operation. At each phase there are many different factors which can affect the quality of the final product. For the complex task there are limitations so factors such as subsystem configuration, working languages, operational profile and so on should be considered. As a result 13 companies participated to identify the 13 factors that may have an impact on software reliability. Their result is based on the 3 hypothesis which are:

a. The significance of impact of 32 factors on Software Reliability Assessment is of the same level.

b. People playing different role in the software

\begin{tabular}{|c|c|}
\hline General & $\begin{array}{l}\text { Program complexity, Program } \\
\text { category, Difficulty of } \\
\text { Programming, Amount of } \\
\text { programming effort, Level of } \\
\text { programming technologies, } \\
\text { Percentage of reused module, } \\
\text { Programming language. }\end{array}$ \\
\hline Analysis and Design & $\begin{array}{l}\text { Frequency of program } \\
\text { specification change, Volume of } \\
\text { program design documents, } \\
\text { Design methodology, } \\
\text { Requirements analysis, } \\
\text { Relationship of detailed design } \\
\text { to requirement, Work standards, } \\
\text { Development management }\end{array}$ \\
\hline Coding & $\begin{array}{l}\text { Programmer skill, Programmer } \\
\text { organization, Development team } \\
\text { size, Program workload (stress), } \\
\text { Domain knowledge, Human } \\
\text { nature (mistake and work } \\
\text { omission) }\end{array}$ \\
\hline Testing & $\begin{array}{lr}\text { Testing } & \text { environment } \\
\text { (duplication of production), } & \text { Testing effort, Testing resource } \\
\text { Testing } & \text { Testing } \\
\text { allocation, } & \text { Testing } \\
\text { methodologies, } & \text { tools, } \\
\text { coverage, Testing } & \\
\text { Documentation } & \end{array}$ \\
\hline Hardware System & $\begin{array}{ll}\text { Processors, Storage } & \begin{array}{l}\text { devices, } \\
\text { devices, } \\
\text { Input/output }\end{array} \\
\text { Telecommunication } & \text { devices, } \\
\text { System software } & \end{array}$ \\
\hline
\end{tabular}
development have same opinion on significance of 32 factors.

c. People developing software for different applications have the same opinion on the importance of the 32 factors.

The 32 factors have been collected and have been clustered in 5 groups on the basis of general, Analysis and Design, Coding, Testing and Hardware System .As the factors may seem externally independent but internally they are correlated to each other. So, these are stated as:

\section{Table 1:Classification Of Factors Of Metrics}

\section{SCOPE AND MOTIVATION}

Software Engineering is a young discipline, so its theories, methods, models and technique need to be fully developed and assessed and the 32 factors stated above can be used to give highly reliable software which is more in demand. Software Engineering measurement is one of the areas in Software Engineering where researchers are active since more than 30 years. Therefore, Software Reliability has become 
more and more important. Software Reliability is a measuring technique for defect that cause software failure. This is the hot topic for research in the field of Software engineering.

\section{OBJECTIVE}

The number of metrics have been proposed during the past years for accessing the reliability of a software system. In this research work we access the performance of metrics factor during the Software Development Cycle. In this research paper we have taken all the 32 factors and ranking is given according to their performance.

\section{RESULTS AND DISCUSSION}

The 32 factors have been statistically analyzed using the SPSS tools in which various parameters have been considered.

\section{GENERAL:}

Table 2 : Correlation Matix

\begin{tabular}{|r|r|r|r|r|r|r|r|}
\hline & var1 & var2 & var3 & var4 & var5 & var6 & $\operatorname{var} 7$ \\
\hline Correlation var1 & 1.000 & .343 & .233 & .240 & .218 & .116 & .162 \\
$\operatorname{var2}$ & .343 & 1.000 & -.004 & .262 & .177 & .423 & .289 \\
$\operatorname{var3}$ & .233 & -.004 & 1.000 & .264 & .141 & .141 & .015 \\
$\operatorname{var4}$ & .240 & .262 & .264 & 1.000 & .284 & .295 & .010 \\
$\operatorname{var5}$ & .218 & .177 & .141 & .284 & 1.000 & .492 & .168 \\
$\operatorname{var6}$ & .116 & .423 & .141 & .295 & .492 & 1.000 & .455 \\
$\operatorname{var7}$ & .162 & .289 & .015 & .010 & .168 & .455 & 1.000 \\
\hline
\end{tabular}

Table 3: Kmo \& Bartlett's Test

\begin{tabular}{|l|l|}
\hline Kaiser-Meyer-Olkin & \\
Measure of Sampling Adequacy & 0.606 \\
Bartlett's Test of Sphericity & \\
Approx. Chi Square & 94.973 \\
Df & 21.000 \\
Sig & \\
\hline
\end{tabular}

Table 4 : Communalities

\begin{tabular}{|l|l|l|}
\hline & Initial & Extraction \\
\hline Var 1 & & 0.373 \\
Var 2 & & 0.478 \\
Var 3 & & 0.557 \\
Var 4 & & 0.540 \\
Var 5 & & 0.412 \\
Var 6 & & 0.690 \\
Var 7 & & 0.599 \\
\hline
\end{tabular}

Extraction method:Principal Component analysis

Table 5: Total Variance Explained

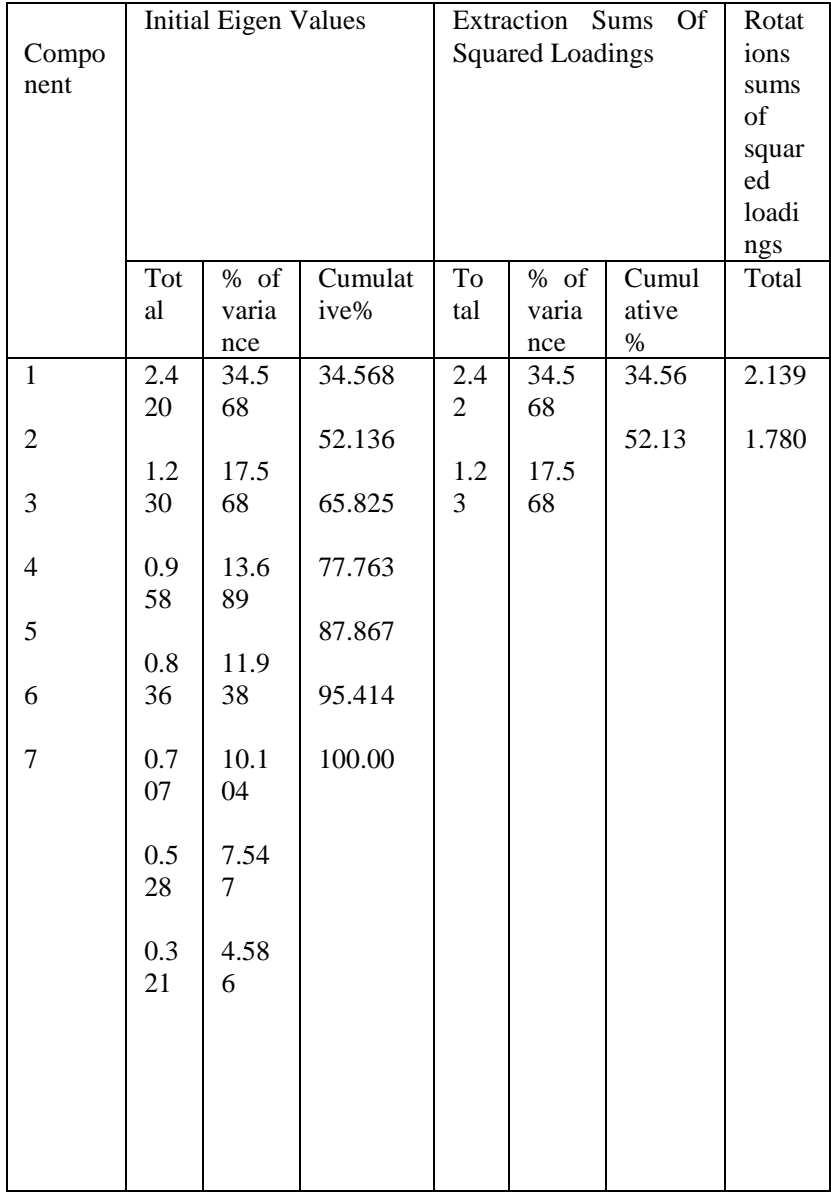

Extraction Method: Principal Component Analysis.

a. When components are correlated, sum of squared Loadings cannot be added to obtain a total variance.

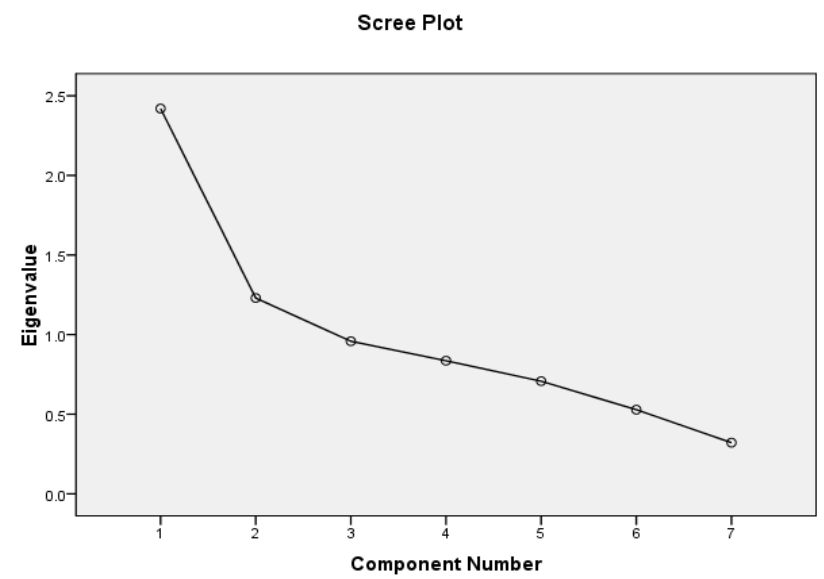

Fig 1: Plotting Of General Metrics Wrt. Eigen Value \& Component Number 
Table 6:Component Matrix

\begin{tabular}{|l|l|l|}
\hline \multirow{2}{*}{} & \multicolumn{3}{|c|}{ Component } \\
\cline { 2 - 4 } Var 6 & 0.776 & \\
Var 2 & & \\
Var 5 & & \\
Var 4 & & \\
Var 1 & & \\
Var3 & & \\
Var 7 & & \\
\end{tabular}

Extraction Method:Principal Component Analysis

a. 2 components Extracted

Table 7:Rotation Method

\begin{tabular}{|c|c|c|}
\hline & & onent \\
\hline & 1 & 2 \\
\hline Var 7 & 0.794 & \\
\hline Var 6 & 0.793 & \\
\hline Var 2 & & \\
\hline Var 5 & & \\
\hline Var 3 & & 0.768 \\
\hline Var 4 & & 0.706 \\
\hline Var 1 & & \\
\hline
\end{tabular}

Extraction Method:Principal Component Analysis Rotation Method: Oblimin with Kaiser Normalization.

Table 8:Structure Matrix

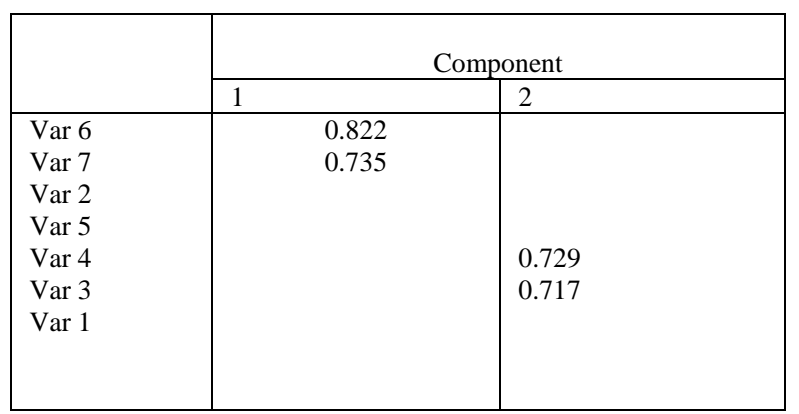

Extraction Method:Principal Component Analysis

Rotation Method: Oblimin with Kaiser Normalization
Analysis

Table 9:Correlation Matrix

\begin{tabular}{|c|c|c|c|c|c|c|c|}
\hline & $\begin{array}{c}\text { Var } \\
1\end{array}$ & $\begin{array}{c}\text { Var } \\
2\end{array}$ & $\begin{array}{c}\text { Var } \\
3\end{array}$ & $\begin{array}{c}\text { Var } \\
4\end{array}$ & $\begin{array}{c}\text { Var } \\
5\end{array}$ & $\begin{array}{c}\text { Var } \\
6\end{array}$ & $\begin{array}{c}\text { Var } \\
7\end{array}$ \\
\hline Var 1 & 1.000 & 0.295 & 0.093 & 0.270 & 0.208 & 0.213 & 0.367 \\
Var 2 & 0.295 & 1.000 & 0.184 & 0.272 & 0.407 & 0.607 & 0.494 \\
Var 3 & 0.093 & 0.184 & 1.000 & 0.479 & 0.482 & 0.335 & 0.162 \\
Var 4 & 0.270 & 0.272 & 0.479 & 1.000 & 0.595 & 0.131 & 0.462 \\
Var 5 & 0.208 & 0.407 & 0.482 & 0.595 & 1.000 & 0.322 & 0.496 \\
Var 6 & 0.213 & 0.607 & 0.335 & 0.131 & 0.322 & 1.000 & 0.523 \\
Var 7 & 0.367 & 0.494 & 0.162 & 0.462 & 0.496 & 0.523 & 1.000 \\
\hline
\end{tabular}

Table 10:Kmo \& Bartlett's Test

\begin{tabular}{|l|l|}
\hline Kaiser-Mayer-Olkin Measure of Sampling & 0.674 \\
Adequacy & \\
Bartlett's Test of Spherecity & \\
Approx Chi square & 187.520 \\
Df & 21.000 \\
Sig & \\
\hline
\end{tabular}

Table 11 : Communalities

\begin{tabular}{|l|l|l|}
\hline & Initial & Extraction \\
\hline Var 1 & 1.000 & 0.298 \\
\hline Var 2 & 1.000 & 0.695 \\
\hline Var 3 & 1.000 & 0.628 \\
\hline Var 4 & 1.000 & 0.735 \\
\hline Var 5 & 1.000 & 0.710 \\
\hline Var 6 & 1.000 & 0.651 \\
\hline Var 7 & 1.000 & 0.656 \\
\hline
\end{tabular}

Extraction Method: Principal Component Analysis

Table 12 :Total Variance Explained

\begin{tabular}{|c|c|c|c|c|c|c|c|}
\hline \multirow[t]{2}{*}{ Component } & \multicolumn{3}{|c|}{ Initial Eigen Values } & \multicolumn{3}{|c|}{$\begin{array}{l}\text { Extraction Sums Of Squared } \\
\text { Loadings }\end{array}$} & \multirow{2}{*}{$\begin{array}{l}\text { Rotation } \\
\text { Sums of } \\
\text { squared } \\
\text { Loadings } \\
\text { Total }\end{array}$} \\
\hline & Total & $\begin{array}{l}\% \text { of } \\
\text { variance }\end{array}$ & $\begin{array}{l}\text { Cumulative } \\
\%\end{array}$ & Total & $\begin{array}{l}\% \text { of } \\
\text { variance }\end{array}$ & $\begin{array}{l}\text { Cumualtive } \\
\%\end{array}$ & \\
\hline
\end{tabular}




\begin{tabular}{|l|l|l|l|l|l|l|l|}
\hline 1 & 3.169 & 45.265 & 45.265 & 3.169 & 45.265 & 45.265 & 2.696 \\
2 & 1.206 & & & 1.206 & & & \\
3 & 0.923 & 17.224 & 62.489 & & 17.224 & 62.489 & 2.443 \\
4 & 0.662 & 13.183 & 75.672 & & & & \\
5 & 0.457 & 9.454 & 85.126 & & & & \\
6 & 0.371 & 6.527 & 91.653 & & & & \\
7 & 0.213 & 5.299 & 96.953 & & & & \\
\hline
\end{tabular}

Extraction Method: Principal Component Analysis

a. When components are correlated sums of squared loadings cannot be added to obtain a total variance.

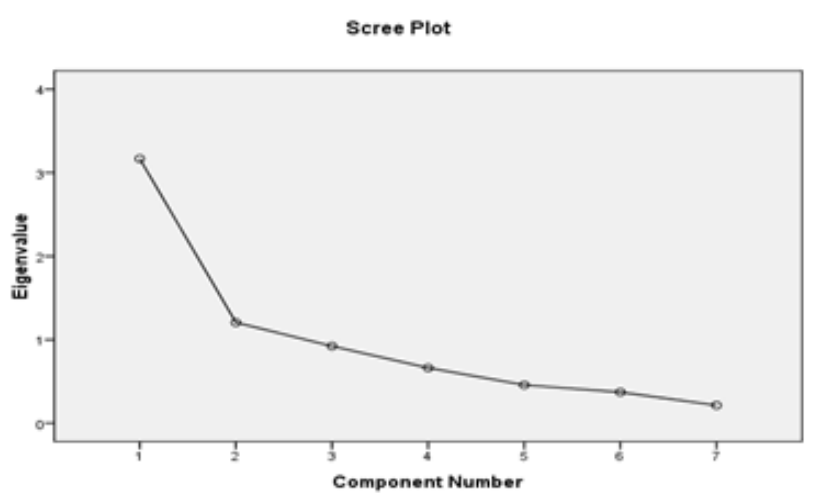

Figure 2:Plotting Of Analysis Factors Wrt To Eigen Values \& Component Number

Table 13:Component Matrix

\begin{tabular}{|l|l|l|l|}
\hline \multirow{4}{*}{} & \multicolumn{2}{|l|}{ Component } & \multicolumn{2}{l|}{} \\
\cline { 2 - 4 } & 1 & 2 & \\
\hline Var 5 & 0.792 & & \\
Var 1 & 0.772 & & \\
Var 6 & & & \\
Var2 & & 0.794 & \\
Var 3 & & & \\
Var 4 & & & \\
\hline
\end{tabular}

Extraction Method:Principal Component Analysis

a. 3 components Extracted
Table 14:Pattern Matrix

\begin{tabular}{|l|c|l|l|}
\hline \multirow{2}{*}{} & \multicolumn{3}{|c|}{ Component } \\
\cline { 2 - 4 } & 1 & 2 & 3 \\
\hline Var 6 & 0.879 & & \\
Var 1 & 0.820 & & \\
Var 5 & & & \\
Var 2 & & 0.917 & -0.894 \\
Var 4 & & & \\
Var 3 & & & \\
\hline
\end{tabular}

Extraction Method:Principal Component Analysis Rotation Method :Oblimin With Kaiser normalization

a. Rotation covered in 10 iterations

\section{Table 15:Structure Matrix}

\begin{tabular}{|c|c|c|c|}
\hline \multirow{2}{*}{} & \multicolumn{3}{|c|}{ Component } \\
\cline { 2 - 4 } & 1 & 2 & 3 \\
\hline Var 1 & 0.844 & & \\
Var 6 & 0.827 & & \\
Var 5 & & & -0.857 \\
Var 2 & & 0.915 & \\
Var 4 & & & \\
Var 3 & & & \\
& & & \\
\hline
\end{tabular}

Extraction Method:Principal Component Analysis Rotation method:Oblimin with Kaiser normalization 
Table 16: Component Correlation Matrix

\begin{tabular}{|l|l|l|l|}
\hline Component & 1 & 2 & 3 \\
\hline 1 & 1.000 & -0.001 & -0.255 \\
3 & -0.001 & 1.000 & -0.013 \\
& -0.255 & -0.013 & 1.000 \\
\hline
\end{tabular}

Extraction Method: Principal Component Analysis Rotation Method : Oblimin With Kaiser normalization

\section{Testing}

Table 17: Correlation Matrix

\begin{tabular}{|l|l|l|l|l|l|l|}
\hline & Var 1 & Var 2 & Var 3 & Var 4 & Var 5 & Var 6 \\
\hline Var 1 & 1.000 & -0.122 & 0.289 & 0.183 & 0.500 & 0.491 \\
Var 2 & -0.122 & 1.000 & 0.193 & -0.167 & -0.194 & -0.124 \\
Var 3 & 0.289 & 0.193 & 1.000 & 0.343 & 0.394 & 0.172 \\
Var 4 & 0.183 & -0.167 & 0.343 & 1.000 & 0.320 & 0.060 \\
Var 5 & 0.500 & -0.194 & 0.394 & 0.320 & 1.000 & 0.299 \\
Var 6 & 0.491 & -0.124 & 0.172 & 0.60 & 0.299 & 1.000 \\
\hline
\end{tabular}

Table 18: Kmo \& Bartlett's Test

\begin{tabular}{|l|l|}
\hline $\begin{array}{l}\text { Kaiser -Meyer-Olkin Measure of Sampling } \\
\text { Adequacy }\end{array}$ & 0.633 \\
Bartlett's Test of Sphericity & \\
Approx Chi square & 84.579 \\
Df & 15.000 \\
Sig & \\
\hline & \\
\hline
\end{tabular}

Table 19:Communalities

\begin{tabular}{|l|l|l|}
\hline & Initial & Extraction \\
\hline Var 1 & 1.000 & 0.722 \\
Var 2 & 1.000 & 0.887 \\
Var 3 & 1.000 & 0.726 \\
Var 4 & 1.000 & 0.773 \\
Var 5 & 1.000 & 0.637 \\
Var 6 & 1.000 & 0.725 \\
\hline
\end{tabular}

Extraction Method: Principal Component Analysis
Table 20:Total Variance Explained

\begin{tabular}{|c|c|c|c|c|c|c|c|}
\hline \multirow{2}{*}{$\begin{array}{c}\text { Compo } \\
\text { nents }\end{array}$} & \multicolumn{3}{|c|}{ Initial Eigen Values } & \multicolumn{3}{|c|}{$\begin{array}{l}\text { Extraction Sum of } \\
\text { squared loadings }\end{array}$} & \multirow{2}{*}{$\begin{array}{c}\text { Rotat } \\
\text { ion } \\
\text { Sums } \\
\text { of } \\
\text { Squar } \\
\text { ed } \\
\text { Loadi } \\
\text { ngs } \\
\text { Total }\end{array}$} \\
\hline & $\begin{array}{c}\text { Tot } \\
\text { al }\end{array}$ & $\begin{array}{c}\% \text { of } \\
\text { Varia } \\
\text { nce }\end{array}$ & $\begin{array}{c}\text { Cumul } \\
\text { ative } \\
\%\end{array}$ & $\begin{array}{c}\text { Tot } \\
\text { al }\end{array}$ & $\begin{array}{c}\% \text { of } \\
\text { varia } \\
\text { nce }\end{array}$ & $\begin{array}{c}\text { Cumul } \\
\text { ative } \\
\%\end{array}$ & \\
\hline 1 & $\begin{array}{l}2.2 \\
85\end{array}$ & $\begin{array}{c}38.08 \\
0\end{array}$ & 38.080 & $\begin{array}{l}2.2 \\
85\end{array}$ & $\begin{array}{l}38.0 \\
80\end{array}$ & & 1.964 \\
\hline 2 & $\begin{array}{l}1.1 \\
88\end{array}$ & $\begin{array}{c}19.79 \\
3\end{array}$ & 57.873 & $\begin{array}{l}1.1 \\
88\end{array}$ & $\begin{array}{l}19.7 \\
93\end{array}$ & 57.873 & 1.160 \\
\hline 3 & $\begin{array}{l}1.0 \\
47\end{array}$ & $\begin{array}{c}17.44 \\
5\end{array}$ & $\begin{array}{l}75.319 \\
85.300\end{array}$ & $\begin{array}{l}1.0 \\
47\end{array}$ & $\begin{array}{l}17.4 \\
45\end{array}$ & 75.319 & 1.697 \\
\hline 5 & $\begin{array}{l}0.5 \\
99\end{array}$ & 9.981 & 93.245 & & & & \\
\hline 6 & $\begin{array}{l}0.4 \\
77 \\
\\
0.4 \\
05\end{array}$ & $\begin{array}{l}7.954 \\
6.755\end{array}$ & 100.00 & & & & \\
\hline
\end{tabular}

Extraction Method: Principal Component Analysis When components are correlated, sum of squared loadings cannot be added to obtain a total variance

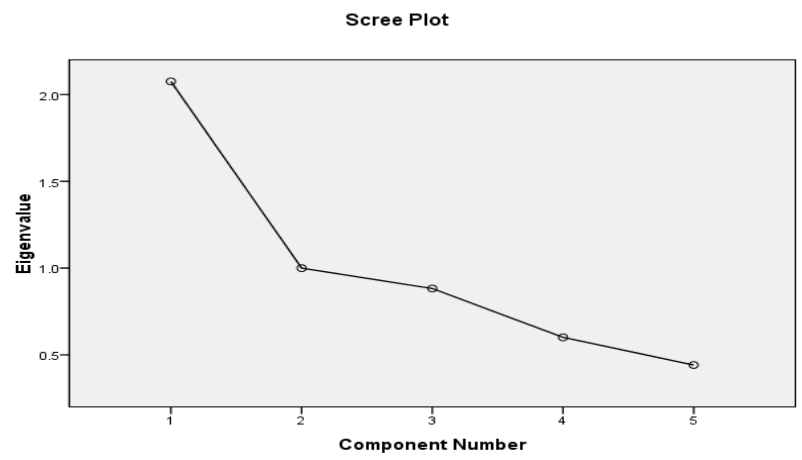

Figure 3:Plotting Of Testing Wrt To Eigen Value And Component Number

Table 21: Component Matrix

\begin{tabular}{|c|c|}
\hline & Component \\
\cline { 2 - 2 } & 1 \\
\hline Var 2 & 0.800 \\
Var 5 & 0.714 \\
Var 1 & 0.681 \\
Var 3 & 0.663 \\
Var 4 & \\
\hline
\end{tabular}




\section{ACKNOWLEDGMENT}

I would like to take this opportunity to express my gratitude to all those people who have in various ways helped us including the college students. My sincere thanks goes to Dr. Saurabh Mukherjee(Associate Professor,Department of Computer Science, Banasthali Vidhyapeeth) for sharing their wisdom, knowledge and expertise to better understand the issues related to this work.

\section{REFERENCES}

[1] Tariq Hassain Sheakh, Vijaypal Singh, "Taxonomical Study of Software Reliability Growth Models",International Journal of Scientific Research Publications, Vol.2, Issue 5, pp-1-3 May 2012
[2] Chandrasekhar Rajaraman, Michael R. Lyu ,Reliability and Maintainability Related Software Coupling Metrics in $\mathrm{C}++$ Programs

[3] Xuemei Zhang, Hoang Pham ,An analysis of factors affecting software reliability The Journal of Systems and Software 50 (2000), page no. 43-56.

[4] Norman F.Schneidewind Methodology for validating software metrics, , IEEE transaction on Software Engineering, vol.18, No. 5 May 1992 page no. 410-422.

[5] Dr. Linda Rosenberg Ted Hammer, Jack Shaw.Software metrics and reliability, 